\title{
SOCIAL ASSISTANCE SERVICES AND INTEGRATED EMPLOYMENT IN BULGARIA
}

\author{
Venelin Terziev \\ Corresponding Member of the Russian Academy of Natural History, Moscow, Russia, Prof. D.Sc. \\ (Ec.), D.Sc. (National Security), D.Sc. (Social Activities), Ph.D., National Military University, Veliko \\ Tarnovo, Bulgaria; University of Rousse, Rousse, Bulgaria, terziev@skmat.com
}

\begin{abstract}
The article presents the implementation of the project for establishing Centres for Employment and Social Assistance in Bulgaria in the period 2015- 2017 as a model of the provision of integrated employment and social assistance services aiming at increasing the efficiency of coordination and work in Employment Agency and Social Assistance Agency and enhancing social inclusion. Services and provided support are analysed and conclusions and recommendations are drawn on the need of better evidence and data on their functioning so that to create reliable instruments for assessment of activities and outcomes.
\end{abstract}

Keywords: Employment, Unemployment, Labour Market.

\section{INTRODUCTION}

Current paper presents an analysis of the activities implemented under the project entitled 'Face To Face services in CESA (Center for employment and social assistance)' on the territory of the Republic of Bulgaria with the support of the Human resources development Operational program 2014-2020. The beneficiary is the Ministry of labour and social policy with a Union co-financing rate of $85 \%$ for the sum of 33000000 BGN.

The project's goal is the improvement of coordination and interaction between the Social Assistance Agency (SAA) and the Employment Agency (EA) in the Republic of Bulgaria by applying a pilot project for mutual services for the citizens of vulnerable social groups and individualization of services.

Centers for Employment and Social Assistance (CESAs) are envisaged to provide advice, orientation and information so that to facilitate the access of unemployed persons and those relying on social support to employment and opportunities of social inclusion through more active servicing and shortening the period of social assistance.

The realization of the project activities has anticipated making an approbation of a model of integrated administrative services.

The following activities are described into the project description in the Information system for management 
and monitoring of EU funds in Bulgaria 2020 -

http://2020.eufunds.bg/bg/1/0/Project/PrintProject?contractld=84:

- Study and analysis of applied methods and processes;

- Preparation of a Methodology for the operation of CESAs in relation to the provided administrative services;

- Establishment of premises for comprehensive servicing of citizens in the CESAs and their technical provision;

- Creating an accessible environment for people with disabilities, if applicable;

- Trainings of the employees in CESAs, incl. mutual learning at the workplace;

- Activities for exchange of experience among the employees in CESAs;

- Providing a new integrated service model by CESAs through a collaborative approach and interaction between the structures of social assistance systems and employment promotion;

- Performing inspections by CESA's staff on the persons serviced by the center;

- Interim evaluation of the effectiveness of the applied pilot model through a comparative analysis of the activities of CESAs and the other service units in the EA and SAA system;

- Analyses of the efficiency and the effectiveness of the new model and making proposals for system change and reform.

CESAs are designed to provide the following services:

Employment services provided to job-seekers and employers

Intermediary services for jobseekers include: information and/or consultation on their rights and obligations under the Employment promotion act; job vacancies and the requirements for their occupation; the opportunities for participation in programs and measures for employment and training; opportunities for education for adults; opportunities of changing the profession and working outside the boundaries of the place of residence; terms and conditions for work in other countries under intergovernmental agreements, etc.

Along with that the following are provided: acceptance of applications and registration of job seekers and related services; targeting and helping to start work, including elsewhere in the country or in other countries within the EURES mobility network; psychological support and motivation for an active behavior on the labour market; targeting and engagement into appropriate programs and measures for employment and training; professional information, counseling and guidance; providing access to public information; answers to queries received through different access channels, etc.

Intermediary services for employers include: providing information on registered jobseekers in certain professions, specialties, professional experience, additional skills and readiness to start work; providing information on programs and measures to preserve and promote employment and training of hired personnel; providing information on the rights and obligations in the mass dismissal of employees; recruitment mediation through providing information on the procedures and ways of announcing vacancies; accepting vacancies; processing and disseminating information about the vacancies; selection of suitable candidates, meeting the requirements of the employer; directing suitable candidates to the relevant workplace; requiring feedback on the results; choosing appropriate employment and training programs and measures; providing information on the issuance of employment permits to foreigners, etc.

Social assistance services provided include:

Informing, advising, targeting and providing assistance to vulnerable citizens according to their individual needs in search of opportunities for their social inclusion and employment: informing, guidance in the procedure of the provision of social services, reception of applications, complaints, alerts and inquiries; providing clear, accurate, reliable, systematized and complete information on the opportunities of social support - conditions, order and method of support, in accordance with the current legislation; targeting and liaising with other institutions responsible for the problem; displaying on prominent information boards normative documents, up-to-date information, sample forms for filling in, important announcements and changes in legislation, "hot" telephone; accessible information for people with disabilities, etc.

Acceptance and processing of applications / declarations and the necessary documents for support on the 
different legal bases, use of social services and issuance of certificates: reception of requests/declarations, verification of the declared and for the necessary documents; processing of the received documents: distribution by regions, conducting a social survey (verification at the person's home, investigation and collection of information), electronic processing, issuing an administrative act and notifying the person concerned about it; methodological and control activities; carrying out on-the-spot checks.

Vulnerable groups on the labour market are regulated in the supplementary provisions of the Employment promotion act as follows: Disadvantaged groups on the labour market are groups of unemployed with lower competitiveness on the labour market which include: unemployed youths; unemployed young people with permanent disabilities; unemployed youths from social institutions who have completed their education; longterm unemployed; unemployed persons with permanent disabilities; unemployed persons - single parents (adoptive parents) and/or mothers (adoptive parents) with children up to 5 years of age. Each year, the National action plan for employment sets the target groups for which the active policy is directed.

The main expected result is the established CESAs to introduce new and/or updated processes and models of planning and implementation of policies and services on the labor market in Bulgaria.

\section{AIM OF THE ANALYSIS}

Assessment of the provision of integrated services at the Centers for employment and social assistance (CESAs) in Bulgaria and their comparison to the provision of non-integrated services, as well as analyses on the measures taken and the process.

\section{RESULTS AND DISCUSSION}

Under the project 73 CPPPs were established, employing EA and SAA staff offering 'one-stop-shop' services for citizens. Centers provide counseling, guidance and information to unemployed and people receiving social support through a new flexible, individualized and integrated approach (Terziev, 2017, 318 str; Terziev, Arabska, 2016, 312 str; Terziev, 2018, 307 p.; Terziev, 2015, 110 p.; Terziev, 2015a, 434 p.; Terziev, Arabska, 2015b, 198 p.; Terziev, Arabska, 2015c; Terziev, Arabska, 2014, str. 3-57; Terziev, 2015d; Terziev, Georgiev, 2018a, str. 970-975; Terziev, Georgiev, 2018b, str. 959-969; Terziev, Georgiev, 2018c, str. 951-958; Terziev, Georgiev, 2018d, str. 188-193; Terziev, Georgiev, 2018e, str. 177-187; Terziev, Georgiev, 2018f, str. 169-176; Terziev, Banabakova, Georgiev, 2018g, pp. 935-944; Terziev, Banabakova, Georgiev, pp. 973-980; Terziev, Banabakova, Georgiev, 2018i, pp. 1275-1281; Terziev, Georgiev, 2018j, pp. 6-15; Terziev, Banabakova, Georgiev, 2018k, s.93-98; Terziev, Banabakova, Georgiev, 2018l, s. 99-104; Terziev, Banabakova, Georgiev, 2018m, s. 104-109; Terziev, Banabakova, Georgiev, 2018n, s. 110-115; Terziev, Banabakova, Georgiev, 2018o, s. 116-121; Terziev, Banabakova, Georgiev, 2018p, s. 122-127; Terziev, Banabakova, Georgiev, 2018q, s. 127-131; Terziev, Banabakova, Georgiev, 2018r, s. 132-137; Terziev, Banabakova, Georgiev, 2018s, s. 137-142; Terziev, Georgiev, 2017a, pp. 94-101).

Data about the establishment and functioning of CESAs, as well as the implementation of the project, could be found in the annual reports of the Ministry of labour and social policy, particularly those of the Employment agency. However, the information provided is not complete and well-structured and thus could not be used in making analyses and comparisons of the impact of the provision of integrated and nonintegrated services.

The results which can be presented and discuss are the following:

- The project activities are implemented according to the plan and the changes imposed in it substantiated by appropriate decisions.

- The number of established CESAs in 2015 is 65 , and following the decision of the monitoring committee of the Human resources development Program 2014-2020 the number is now 73.

- In 2015, as a result of CESAs' operation and the services provided by them, 69812 persons were employed, out of which 45066 - on the primary labour market. 11823 long-term unemployed persons are employed which have been registered in the labour offices for more than 12 months. During the period January - December 2015 complex services were provided to a total of 408106 persons and families with unemployed members (Table 1) among which 181009 persons with disabilities and their families and 155 999 families with children. 
Table 1. Results of CESAs' operation for 2015

\begin{tabular}{|l|l|}
\hline $\begin{array}{l}\text { Type of support / persons benefiting consulting and information services } \\
\text { provided by CESAs }\end{array}$ & $\begin{array}{l}\text { Number of persons / families } \\
\text { involved in the support } \\
\text { measures as a result of } \\
\text { CESAs' functioning }\end{array}$ \\
\hline Employed persons & 69812 \\
\hline incl. on the primary labour market & 45066 \\
\hline $\begin{array}{l}\text { Employed persons among the long-term unemployed having a registration in } \\
\text { labour offices for more than 12 months }\end{array}$ & 11823 \\
\hline Complex services for families with unemployed members & 408106 \\
\hline monthly support under the Social assistance act of the country & 11756 \\
\hline monthly support for children & 155929 \\
\hline targeted support for heating & 57403 \\
\hline monthly supplements for social integration of persons with disabilities & 181009 \\
\hline appointed personal assistants for persons with permanent disabilities & 644 \\
\hline
\end{tabular}

- In 2016, as a result of the work of CESAs, 76552 persons were employed, of which 52404 on the primary labor market. 14436 long-term unemployed have started work. 19091 unemployed persons have been benefiting of social support, out of which 7658 were employed (5 419 persons - on the primary labor market, 1021 - under programs and measures according to the Employment promotion act, and 1017 persons - under Human resources development Operational program schemes); 226 persons were enrolled in training, and more than 27800 have received services for an active labor market behavior (job search, psychological assistance, etc.) (Table 2).

- In 2016, in the municipalities on whose territory the project is being implemented, the average monthly number of persons and families with unemployed members who have been supported as a result of consulting and information services provided by CESAs shows a clear orientation towards people with disabilities and their families (177 105) and families with children (134 918) (Table 2) as is the case for 2015 (Table 1).

Table 2. Results of CESAs' operation for 2016

\begin{tabular}{|l|r|}
\hline \multicolumn{1}{|c|}{$\begin{array}{c}\text { Type of support / persons benefiting consulting and information services } \\
\text { provided by CESAs }\end{array}$} & $\begin{array}{c}\text { Number of persons / families } \\
\text { involved in the support } \\
\text { measures as a result of } \\
\text { CESAs' functioning }\end{array}$ \\
\hline Employed persons & 76552 \\
\hline incl. on the primary labour market & 52404 \\
\hline Employed persons among long-term unemployed & 14436 \\
\hline $\begin{array}{l}\text { Average monthly number of persons / families with unemployed members } \\
\text { supported }\end{array}$ & 379866 \\
\hline under the Social assistance act & 10094 \\
\hline monthly support for children & 134918 \\
\hline targeted support for heating & 57157 \\
\hline support for people with disabilities & 177105 \\
\hline appointed assistants for persons with disabilities & 592 \\
\hline Persons / families benefiting social assistance & 19091 \\
\hline Involved in training & 226 \\
\hline Persons / families benefiting of services for an active labour market behavior & 27800 \\
\hline
\end{tabular}

- Available data for 2017 are not complete - presented till 30.09.2017 (Table 3). 
Table 3. Results of CESAs' operation for 2017

\begin{tabular}{|l|l|}
\hline $\begin{array}{l}\text { Type of support / persons benefiting consulting and information services } \\
\text { provided by CESAs }\end{array}$ & $\begin{array}{l}\text { Number of persons / families } \\
\text { involved in the support } \\
\text { measures as a result of } \\
\text { CESAs' functioning }\end{array}$ \\
\hline Total number of registered unemployed & 60849 \\
\hline incl. those benefiting social support & 2282 \\
\hline Unemployed persons receiving social support becoming employed & 8077 \\
\hline on the primary labour market & 6529 \\
\hline under program and measures according to the Employment promotion act & 899 \\
\hline under Human resources development operational program schemes & 649 \\
\hline Involved in training & 706 \\
\hline Benefiting services for an active labour market behavior & 14301 \\
\hline Targeted support for heating & 29358 \\
\hline
\end{tabular}

- From the information available it is clear that the project implementation continues in 2018 with some new services while the priority in the work of CESAs is the servicing of long-term unemployed persons with registration in the labor offices of over 12 months who are also a subject to social assistance. The package of individualized labor market measures is upgraded with new services focused on education, training and social inclusion. The main goal is to provide a comprehensive service to unemployed people from regions with high levels of unemployment, as well as hard-to-reach and remote settlements.

The main conclusion that could be drawn from the review of the available information and data about the project implementation is that there is a profound lack of public on-line information on the results of the activities. The analyses of the work and the processes, the methodology for the operation of CESAs, interim project reports, etc. are unclear.

Regarding their establishment it is observed that the most often case is that in labour offices (where unemployed or others interested in employment go to register or search for information) an additional desk for an officer from SAA is placed which provides information and forms for the social support services which does not corresponds in fully to the main idea of integration of services.

As it was already mentioned, the data collected are not enough to conclude on the effects of the work of CESAs and to make comparisons with the situation before their establishment and with the places without such centers during the project implementation.

In addition, short interviews according to a unified template of questions with 11 respondents participating in CESAs' activities were conducted. The summarized answers are presented in Annex 1.

Annex 1. Summarized results of the interviews conducted

\begin{tabular}{|l|l|l|}
\hline № & \multicolumn{1}{|c|}{ Questions } & \multicolumn{1}{c|}{ Answers } \\
\hline I. & $\begin{array}{l}\text { What is the value added of the CESA } \\
\text { provision of services compared to } \\
\text { separate provision by PES and Social } \\
\text { Assistance Agency? }\end{array}$ & $\begin{array}{l}\text { 4 of the respondents can't answer, 7 of respondents think } \\
\text { that they provide services and advice to the unemployed. }\end{array}$ \\
\hline II. & $\begin{array}{l}\text { Is there a difference in the effect of } \\
\text { integration on the different groups of } \\
\text { clients (unemployed, long-term } \\
\text { unemployed, GMI beneficiaries, } \\
\text { inactive? (One should make a } \\
\text { differentiation between GMI } \\
\text { (Guaranteed Minimum Income) } \\
\text { beneficiaries and the other inactive) }\end{array}$ & $\begin{array}{l}\text { 5 respondents can't answer or do not know; 5 respondents } \\
\text { respond with YES; one respondent thinks that there are } \\
\text { serious ethnic, education and qualification issues which } \\
\text { affect the integration process and its impact. }\end{array}$ \\
\cline { 2 - 3 } & $\begin{array}{l}\text { Is there a proper case management } \\
\text { for LTU thanks to the centres? }\end{array}$ & $\begin{array}{l}\text { To this question respondents can't answer. } \\
\text { III. }\end{array}$ \\
$\begin{array}{l}\text { Can a targeted benchmark for } \\
\text { integration be provided? }\end{array}$ & $\begin{array}{l}\text { 3 of the respondents do not know, 7 think that further } \\
\text { analysis is needed, one considers that such indicators are: } \\
\text { employment rate, unemployment rate, percentage of the } \\
\text { unemployed found a job }\end{array}$ \\
\hline
\end{tabular}


IJASOS- International E-Journal of Advances in Social Sciences, Vol. IV, Issue 12, December 2018

\begin{tabular}{|c|c|c|}
\hline & $\begin{array}{l}\text { How is the integration working in } \\
\text { practice and can the "distance" of } \\
\text { actual from the benchmark be } \\
\text { assessed? }\end{array}$ & $\begin{array}{l}6 \text { of respondents thinks that will be through cooperation } \\
\text { between the different institutions, } 5 \text { believe that family and } \\
\text { relatives have a major role in integration. }\end{array}$ \\
\hline & $\begin{array}{l}\text { How is establishing of social } \\
\text { assistance rights and provision of } \\
\text { benefits complemented with social } \\
\text { service provision? }\end{array}$ & $\begin{array}{l}\text { One of the respondents considered the provision of training } \\
\text { vouchers to the target groups, } 10 \text { respondents answered: } \\
\text { through interaction between different institutions and } \\
\text { interaction between SAA and EA. }\end{array}$ \\
\hline & $\begin{array}{l}\text { How could the municipalities be } \\
\text { involved? }\end{array}$ & $\begin{array}{l}\text { One respondent believes that they should be involved and } \\
\text { participate in more programs, } 10 \text { respondents think this } \\
\text { could be with the participation of social assistance } \\
\text { subdivisions, social activities directorates or related social } \\
\text { departments and units. }\end{array}$ \\
\hline \multirow[t]{5}{*}{ IV. } & $\begin{array}{l}\text { Could the expert provide a clear } \\
\text { description of the measures which are } \\
\text { effective and which could be further } \\
\text { developed? }\end{array}$ & $\begin{array}{l}\text { One of the respondents thinks by controlling each level of } \\
\text { service delivery, } 10 \text { respondents think that measures can } \\
\text { be further developed and cooperation between different } \\
\text { institutions is needed. }\end{array}$ \\
\hline & $\begin{array}{l}\text { How could the integration be } \\
\text { improved and bring more people into } \\
\text { the labour market? }\end{array}$ & $\begin{array}{l}\text { Through legislative changes, by increasing confidence in } \\
\text { the institutions and improving the work of different } \\
\text { institutions, creating an integrated system for more efficient } \\
\text { work and coordination in different institutions. }\end{array}$ \\
\hline & $\begin{array}{l}\text { Are the integrated centres making the } \\
\text { most of the advantages of an } \\
\text { integrated approach? }\end{array}$ & $\begin{array}{l}4 \text { of the respondents can't answer, } 3 \text { answered with YES, } 4 \\
\text { of the respondents consider that their efforts are not } \\
\text { enough, more publicity, disclosure and more skills in the } \\
\text { provision of services, including counseling and training, are } \\
\text { needed. }\end{array}$ \\
\hline & What is lacking? & $\begin{array}{l}\text { Lack of will in the legislature and the executive powers, and } \\
\text { greater publicity. }\end{array}$ \\
\hline & $\begin{array}{l}\text { Your recommendations for } \\
\text { improvements: }\end{array}$ & $\begin{array}{l}\text { Respondents believe that greater publicity, disclosure, } \\
\text { accountability and media empowerment are needed. }\end{array}$ \\
\hline \multirow[t]{2}{*}{ V. } & $\begin{array}{l}\text { What is the state of integration of } \\
\text { CESA within the existing network of } \\
\text { stakeholders/ institutions (public, } \\
\text { private, third sector organizations)? }\end{array}$ & $\begin{array}{l}\text { Half of respondents can't answer, others think that there is } \\
\text { a low degree of integration, institutions act on the } \\
\text { presumption of stakeholders. }\end{array}$ \\
\hline & $\begin{array}{l}\text { What will be the best model of the } \\
\text { services functioning? }\end{array}$ & $\begin{array}{l}\text { All respondents believe that more coordination and } \\
\text { interaction, cooperation between all participants (different } \\
\text { institutions) is needed. }\end{array}$ \\
\hline
\end{tabular}

Number and profile of the respondents: 11 respondents participating in CESAs' activities

Specific questions about the efficiency of the integration in CESAs in offering integrated services for disadvantaged groups

- What is the added value of the provision of services by CESAs in relation to their individual provision by labour offices and SAA Centers?

The added value of provision of integrated services lies in the way of work with target groups and the provision of consulting and information about different opportunities of employment and social assistance in one place. If implemented properly, such activities would lead not only to raising the number of beneficiaries of different services as a quantitative impact in result of better information provision and facilitation of access to employment and social assistance for inclusion. The most important would be the raising in the effectiveness of work of officers, now divided in two agencies - for employment and for social assistance. However the implementation of the discussed project as a model is not the best example because of a number of reasons among which the main is the following: the project is designed so as to answer the specific requirements of the operational program and EU funding and there is a little space for flexibility in the framework of the project implementation - if something needs to be changed or done in a different way, there are lots of constraints because of the targeted financing of certain activities as described in the project proposal. But the analyses of the project work and the models could provide the needed basis for subsequent administrative changes in both agencies and the ways of providing employment and social support to vulnerable groups. 
- Is there a difference in the effect of service integration on different groups of clients (unemployed, longterm unemployed, inactive ones, etc.)? Are there suitable models for long-term unemployed support through these centers?

As it was already stated at this moment there is no enough information and data from the project to make comparisons. Moreover, the information and consulting in CESAs (i.e. the results) is dependent on the programs and measures for each year as set by the ministry. This means that the targeted measures, some of the priority target groups and budget vary from year to year and in such case it is impossible to assess the impact or to foresee the effects anticipated in next years. The numbers presented in reports about CESAs so far should not be the only one indicator, neither the project implementation in itself at all. It is undisputable that the long-term unemployed are a group of special treatment as a whole, and in CESAs in particular, but if the prevention measures and the analyses of the reasons for this situation are not available, the problem will stay and grow.

- Can a measurable level of service integration be set? How does service integration happen in practice and can the "degree of discrepancy" between actual and planned integration levels be assessed? How do social assistance entitlements and benefits provided complement the provision of social services? How can municipalities be involved?

Once again, it should be emphasized that in the project implementation (as CESAs are designed) a complete integration could not be achieved. In this case it will be very difficult to set certain indicators, to plan, measure and compare the outcomes and the impacts both quantitatively and qualitatively. However, as initial and piloting steps the project activities are valuable from the point of view of capacity building in the administrative structures in municipalities involved but the decisions for continuation and next development should be based on profound analyses and broad public consultations. As already some discussions go, future reforms (incl. structural ones) in the agencies of the Ministry of labour and social services can be expected to be oriented namely to their integration.

\section{CONCLUSION}

The provision of comprehensive services in support of vulnerable groups through multidisciplinary and crosssectoral approaches by joint teams of the EA and the SAA in CESAs aims at preventing social exclusion and improving the quality of life as well as building a smooth transition between passive receiving of support to lasting employment.

Regarding their specific objectives' implementation as they are set in the project of their establishment in Bulgaria (financed under Human resources development Operational program) the following main outcomes are achieved:

Applying in pilot a new administrative service model integrating employment with other social policies;

Gaining experience and enhancing the capacity of staff in institutions responsible for developing and implementing policies for socially vulnerable groups, as well as developing their knowledge and skills to undertake and implement activities, solutions and policies that are adequate to identified needs.

At this moment of crucial importance is to perform a study on the satisfaction of service providers (institutions as a whole, and officers involved) and their beneficiaries - target groups, to collect their assessments and opinions about the advantages and disadvantages of the integrated model and its probable introduction in the whole system. For that a comprehensive methodology is needed which to serve not only the needs of the project reporting but the needs of information and analyses for the decisions which should be taken for further development of policies and structures (Dimitrova, Georgiev 2017b, s. 204-235; Dimitrova, Georgiev, 2017c, s. 235-258; Terziev, Georgiev, 2017d, pp. 1418-1437; Terziev, Georgiev, 2017e, pp. 24-31; Terziev, Georgiev, 2017f, pp. 32-34; Georgiev, 2017g, pp. 139-143; Terziev, Banabakova, Georgiev, 2017h, s.64-69; Terziev, Banabakova, Georgiev, 2017i, s.70-75; Terziev, Banabakova, Georgiev, 2017j, s.76-81; Terziev, Banabakova, Georgiev, 2017k; s. 103-106; Terziev, Banabakova, Georgiev, 2017I, s. 100-103; Terziev, Banabakova, Georgiev, 2017m, s. 97-100; Terziev, Banabakova, Latyshev, Georgiev, 2017n, pp. 773-791; Terziev, Nichev, Stoyanov, Georgiev, 2017o, pp. 707-710; Terziev, Nichev, Stoyanov, Georgiev, Bogdanov, 2017p, pp. 701-706; Terziev, Nichev, Stoyanov, Georgiev, 2017q, pp. 695-700; Terziev, Nichev, Stoyanov, Georgiev, 2017r, pp. 690-694; Terziev, Latyshev, Georgiev, 2017s, pp.754-772; Terziev, Latyshev, Georgiev, 2017t, pp. 638-659; Terziev, Nichev, Stoyanov, Georgiev, 2017u, pp. 888-892; Terziev, Nichev, Stoyanov, Georgiev, 2017v, pp. 893-898; Terziev, Nichev, Stoyanov, Georgiev, Bogdanov, 2017w, pp. 903908; Terziev, Nichev, Stoyanov, Georgiev, 2017x, pp. 909-912; Terziev, Banabakova, Latyshev, O., Georgiev, 2017y, pp. 1056-1074). 
IJASOS- International E-Journal of Advances in Social Sciences, Vol. IV, Issue 12, December 2018

\section{REFERENCE LIST}

Terziev, Venelin. (2017). Politiki i instrumenti za sotsialno razvitie, Innovations and Sustainability Academy, 2017, ISBN 978-619-7246-14-8, 318 str. (Terziev, Venelin. Политики и инструменти за социално развитие, Innovations and Sustainability Academy, 2017, ISBN 978-619-7246-14-8, 318 стр.).

Terziev, V., E. Arabska, (2016). Effektivnoe vliyanie na raynok truda posredstvom uluchsheniya realizatsii sotsialynoy politiki. Novosibirsk: Izdatelystvo TSRNS, 2016. ISBN 978-5-00068-496-2, 312 str. (Терзиев, В., Е. Арабска, Эфрфективное влияние на рынок труда посредством улучшения реализации социальной политики. Новосибирск: Издательство ЦРНС, 2016. ISBN 978-5-00068496-2, 312 стр).

Terziev, Venelin. (2018). Sotsialno razvitie- politiki i instrumenti, Nauchen institut za menaџment i znaeњe, Skopje, 2018, ISBN 978-608-4834-02-1, 307 р. (Терзиев, Венелин. Социално развитие- политики и инструменти, Научен институт за менаџмент и знаење, Скопје, 2018, ISBN 978-608-4834-02-1, 307 p).

Terziev, Venelin. (2015). Assessment of active social policies impact of social policies on transformation processes in Bulgarian economy, Moscow, 2015, Publisher „Перо“, 110 p. (Publisher „Pero“).

Terziev, Venelin. (2015a). Impact of active social policies and programs in the period of active economic transformations in Bulgaria,,East West"Association for Advanced Studies and Higher Education, Vienna, 2015, ISBN 78-3-903063-44-0, 434 p.

Terziev, V., E. Arabska. (2015b). Theoretical and methodological basis of social programming and social activity, Kolektivnaya monografiya 2015, Ufa, Aeterna. Rossiya.ISBN 978-5-906808-20-2, 198 p. (Terziev, V., E. Arabska, Theoretical and methodological basis of social programming and social activity, Колективная монография 2015, Уфра, Аэтерна. Россия.ISBN 978-5-906808-20-2, 198 р).

Terziev, V., E. Arabska. (2015c). Organic production and management in the Republic of Bulgaria contributing to sustainable development and assurance of safe and healthy living environment, Kolektivnaya monografiya, 2015, Ufa, Aeterna. Rossiya. (monografiya). ISBN 978-906781-40-6 (Terziev, V., E. Arabska, Organic production and management in the Republic of Bulgaria contributing to sustainable development and assurance of safe and healthy living environment, Колективная монографрия, 2015, Уфра, Аэтерна. Россия. (монографрия). ISBN 978-906781-40-6).

Terziev, V., E. Arabska. (2014). Assessment of active social policies' impacts on labor market in the Republic of Bulgaria. Kolektivnaya monografiya "Sotsialyno-ekonomicheskie i pravovay razvitiya ekonomiki", Ufa, Aeterna. Rossiya, 2014. Retsenzetay: Shaybakov R.N., d.e.n., prof, Yangirov A.V. d.e.n., prof. ISBN 978-5-906769-97-8, str. 3-57 (Terziev, V., E. Arabska. Assessment of active social policies' impacts on labor market in the Republic of Bulgaria. Колективная монографрия „Социальноэкономические и правовы развития экономики“, Уфа, Аэтерна. Россия, 2014. Рецензеты: Шайбаков Р.Н., д.э.н., профр, Янгиров А.В. д.э.н., проф. ISBN 978-5-906769-97-8, стр. 3-57).

Terziev, Venelin. (2015d). Analyses of Labor Market Development in the Republic of Bulgaria and the influence of the transition period, TSRNS, Novosibirsk, Rossiya, 30.04.2015 (Terziev, Venelin. Analyses of Labor Market Development in the Republic of Bulgaria and the influence of the transition period, ЦРНС, Новосибирск, Россия, 30.04.2015).

Terziev, V., Georgiev, M. (2018a). Sotsialna zashtita na uyazvimite grupi ot naselenieto v Balgariya. // Sbornik dokladi ot godishna universitetska nauchna konferentsiya 14-15 yuni 2018 g., Elektronno izdanie, NVU Vasil Levski- Veliko Tarnovo, Veliko Tarnovo, 2018, str. 970-975, ISBN 978-619-724620-9 (online e-book), ISSN 2367-7481 (Терзиев, В., Георгиев, М. Социална защита на уязвимите групи от населението в България. // Сборник доклади от годишна университетска научна конфреренция 14-15 юни 2018 г., Електронно издание, НВУ Васил Левски- Велико Търново, Велико Търново, 2018, стр. 970-975, ISBN 978-619-7246-20-9 (online e-book), ISSN 2367-7481).

Terziev, V., Georgiev, M. (2018b). Harakteristiki na sistemata za sotsialno podpomagane. // Sbornik dokladi ot godishna universitetska nauchna konferentsiya 14-15 yuni 2018 g., Elektronno izdanie, NVU Vasil Levski- Veliko Tarnovo, Veliko Tarnovo, 2018, str. 959-969, ISBN 978-619-7246-20-9 (online e-book), ISSN 2367-7481 (Терзиев, В., Георгиев, М. Характеристики на системата за социално подпомагане. // Сборник доклади от годишна университетска научна конференция 14-15 юни 2018 г., Електронно издание, НВУ Васил Левски- Велико Търново, Велико Търново, 2018, стр. 959-969, ISBN 978-619-7246-20-9 (online e-book), ISSN 2367-7481).

Terziev, V., Georgiev, M. (2018c). Podhodi pri obuchenie v organizatsiyata. // Sbor-nik dokladi ot godishna 
universitetska nauchna konferentsiya 14-15 yuni 2018 g., Elek-tronno izdanie, NVU Vasil LevskiVeliko Tarnovo, Veliko Tarnovo, 2018, str. 951-958, ISBN 978-619-7246-20-9 (online e-book), ISSN 2367-7481 (Терзиев, В., Георгиев, М. Подходи при обучение в организацията. // Сбор-ник доклади от годишна университетска научна конференция 14-15 юни 2018 г., Елек-тронно издание, НВУ Васил Левски- Велико Търново, Велико Търново, 2018, стр. 951-958, ISBN 978619-7246-20-9 (online e-book), ISSN 2367-7481).

Terziev, V., Georgiev, M. (2018d). Sotsialna zashtita na uyazvimite grupi ot naselenieto v Balgariya. // Sbornik dokladi ot Godishna universitetska nauchna konferentsiya 14-15 yuni 2018g., Nauchno napravlenie „Sotsialni, stopanski i pravni nauki”, NVU Veliko Tarnovo, Veliko Tarnovo, Izdatelski kompleks na NVU „Vasil Levski”, 7, 2018, str. 188-193, ISBN 978-619-7246-20-9 (online e-book), ISSN 1314-1937 (Терзиев, В., Георгиев, М. Социална защита на уязвимите групи от населението в България. // Сборник доклади от Годишна университетска научна конференция 14-15 юни 2018г., Научно направление „Социални, стопански и правни науки”, НВУ Велико Търново, Велико Търново, Издателски комплекс на НВУ „Васил Левски”, 7, 2018, стр. 188-193, ISBN 978619-7246-20-9 (online e-book), ISSN 1314-1937).

Terziev, V., Georgiev, M. (2018e). Harakteristiki na sistemata za sotsialno podpomagane. // Sbornik dokladi ot Godishna universitetska nauchna konferentsiya 14-15 yuni 2018g., Nauchno napravlenie „Sotsialni, stopanski i pravni nauki”, NVU Veliko Tarnovo, Veliko Tarnovo, Izdatelski kompleks na NVU „Vasil Levski”, 7, 2018, str. 177-187, ISBN 978-619-7246-20-9 (online e-book), ISSN 1314-1937 (Терзиев, В., Георгиев, М. Характеристики на системата за социално подпомагане. // Сборник доклади от Годишна университетска научна конференция 14-15 юни 2018г., Научно направление „Социални, стопански и правни науки”, НВУ Велико Търново, Велико Търново, Издателски комплекс на НВУ „Васил Левски”, 7, 2018, стр. 177-187, ISBN 978-619-7246-20-9 (online e-book), ISSN 1314-1937).

Terziev, V., Georgiev, M. (2018f). Podhodi pri obuchenie v organizatsiyata. // Sbornik dokladi ot Godishna universitetska nauchna konferentsiya 14-15 yuni 2018g., Nauchno napravlenie „Sotsialni, stopanski i pravni nauki”, NVU Veliko Tarnovo, Veliko Tarnovo, Izdatelski kompleks na NVU „Vasil Levski”, 7, 2018, str. 169-176, ISBN 978-619-7246-20-9 (online e-book), ISSN 1314-1937 (Терзиев, В., Георгиев, М. Подходи при обучение в организацията. // Сборник доклади от Годишна университетска научна конфреренция 14-15 юни 2018г., Научно направление „Социални, стопански и правни науки", НВУ Велико Търново, Велико Търново, Издателски комплекс на НВУ „Васил Левски”, 7, 2018, стр. 169-176, ISBN 978-619-7246-20-9 (online e-book), ISSN 13141937).

Terziev, V., Banabakova, V., Georgiev, M. (2018g). Modern dimensions of social policies. // International journal scientific papers Vol 23.4 Promoted in Budva, Montenegro 24-27.05.2018, IKM - Skopje, 23, 2017, N 4, pp. 935-944, ISSN 1857-923X (for e-version) ISSN 2545- 4439 (for printed version).

Terziev, V., Banabakova, V., Georgiev, M. (2018h). Social support as part of social policy. // International journal scientific papers Vol 23.4 Promoted in Budva, Montenegro 24-27.05.2018, IKM - Skopje, 23, 2017, N 4, pp. 973-980, ISSN 1857-923X (for e-version) ISSN 2545 - 4439 (for printed version).

Terziev, V., Banabakova, V., Georgiev, M. (2018i). Structure of the social welfare system in Bulgaria. // International journal scientific papers Vol 23.4 Promoted in Budva, Montenegro 24-27.05.2018, IKM Skopje, 23, 2017, N 4, pp. 1275-1281, ISSN 1857-923X (for e-version) ISSN 2545 - 4439 (for printed version).

Terziev, V., Georgiev, M. (2018j). Efficient management as optimization of the organization. // IJAEDUInternational E-Journal of Advances in Education, April 2018, International Organization Center of Academic Research, www.ocerints.org, Istanbul, Turkey, 2018, pp. 6-15, 4, 2018, N 10, e-ISSN: 2411183X.

Terziev, V., Banabakova, V., Georgiev, M. (2018k). Role and place of social programing in public governance. // Mizhnarodnoï naukovo-praktichnoï konferentsiï «Zabezpechennya stalogo rozvitku ekonomiki: problemi, mozhlivosti, perspektivi» (16-17 lyutogo 2018 roku, m. Uzhgorod), Ministerstvo osviti i nauki Ukraïni Uzhgorodsykiy natsionalyniy universitet, 2018, s.93-98, ISBN 978-966-916-488-9 (Terziev, V., Banabakova, V., Georgiev, M. Role and place of social programing in public governance. // Міжнародної науково-практичної конференції «Забезпечення сталого розвитку економіки: проблеми, можливості, перспективи» (16-17 лютого 2018 року, м. Ужгород), Міністерство освіти і науки України Ужгородський національний університет, 2018, с.93-98, ISBN 978-966-916-488-9). 
IJASOS- International E-Journal of Advances in Social Sciences, Vol. IV, Issue 12, December 2018

Terziev, V., Banabakova, V., Georgiev, M. (2018I). Social program as a product of social programming. // Mizhnarodnoï naukovo-praktichnoï konferentsiï «Zabezpechennya stalogo rozvitku ekonomiki: problemi, mozhlivosti, perspektivi» (16-17 lyutogo 2018 roku, m. Uzhgorod), Ministerstvo osviti i nauki Ukraïni Uzhgorodsykiy natsionalyniy universitet, 2018, s. 99-104, ISBN 978-966-916-488-9 (Terziev, V., Banabakova, V., Georgiev, M. Social program as a product of social programming. // Міжнародної науково-практичної конфреренції «Забезпечення сталого розвитку економіки: проблеми, можливості, перспективи» (16-17 лютого 2018 року, м. Ужгород), Міністерство освіти і науки України Ужгородський національний університет, 2018, с. 99-104, ISBN 978-966-916-488-9).

Terziev, V., Banabakova, V., Georgiev, M. (2018m). Social efficiency as a measure of social activities. // Mizhnarodnoï naukovo-praktichnoï konferentsiï «Zabezpechennya stalogo rozvitku ekonomiki: problemi, mozhlivosti, perspektivi» (16-17 lyutogo 2018 roku, m. Uzhgorod), Ministerstvo osviti i nauki Ukraïni Uzhgorodsykiy natsionalyniy universitet, 2018, s. 104-109, ISBN 978-966-916-488-9 (Terziev, V., Banabakova, V., Georgiev, M. Social efficiency as a measure of social activities. // Міжнародної науково-практичної конференції «Забезпечення сталого розвитку економіки: проблеми, можливості, перспективи» (16-17 лютого 2018 року, м. Ужгород), Міністерство освіти і науки України Ужгородський національний університет, 2018, с. 104-109, ISBN 978-966-916-488-9).

Terziev, V., Banabakova, V., Georgiev, M. (2018n). Assessment of the effectiveness of social programing. // Mizhnarodnoï naukovo-praktichnoï konferentsiï «Zabezpechennya stalogo rozvitku ekonomiki: problemi, mozhlivosti, perspektivi» (16-17 lyutogo 2018 roku, m. Uzhgorod), Ministerstvo osviti i nauki Ukraïni Uzhgorodsykiy natsionalyniy universitet, 2018, s. 110-115, ISBN 978-966-916-488-9 (Terziev, V., Banabakova, V., Georgiev, M. Assessment of the effectiveness of social programing. // Міжнародної науково-практичної конфреренції «Забезпечення сталого розвитку економіки: проблеми, можливості, перспективи» (16-17 лютого 2018 року, м. Ужгород), Міністерство освіти і науки України Ужгородський національний університет, 2018, с. 110-115, ISBN 978-966-916-4889).

Terziev, V., Banabakova, V., Georgiev, M. (20180). Social activity of human resource as a basis of effective social policy. // Mizhnarodnoï naukovo-praktichnoï konferentsiï «Zabezpechennya stalogo rozvitku ekonomiki: problemi, mozhlivosti, perspektivi» (16-17 lyutogo 2018 roku, m. Uzhgorod), Ministerstvo osviti i nauki Ukraïni Uzhgorodsykiy natsionalyniy universitet, 2018, s. 116-121, ISBN 978-966-916488-9 (Terziev, V., Banabakova, V., Georgiev, M. Social activity of human resource as a basis of effective social policy. // Міжнародної науково-практичної конфреренції «Забезпечення сталого розвитку економіки: проблеми, можливості, перспективи» (16-17 лютого 2018 року, м. Ужгород), Міністерство освіти і науки України Ужгородський національний університет, 2018, с. 116-121, ISBN 978-966-916-488-9).

Terziev, V., Banabakova, V., Georgiev, M. (2018p). Strategic advantages of an active social program. // Mizhnarodnoï naukovo-praktichnoï konferentsiï «Zabezpechennya stalogo rozvitku ekonomiki: problemi, mozhlivosti, perspektivi» (16-17 lyutogo 2018 roku, m. Uzhgorod), Ministerstvo osviti i nauki Ukraïni Uzhgorodsykiy natsionalyniy universitet, 2018, s. 122-127, ISBN 978-966-916-488-9 (Terziev, V., Banabakova, V., Georgiev, M. Strategic advantages of an active social program. // Міжнародної науково-практичної конференції «Забезпечення сталого розвитку економіки: проблеми, можливості, перспективи» (16-17 лютого 2018 року, м. Ужгород), Міністерство освіти і науки України Ужгородський національний університет, 2018, с. 122-127, ISBN 978-966-916-488-9).

Terziev, V., Banabakova, V., Georgiev, M. (2018q). Assessment of the effectiveness of social programming. // Mizhnarodnoï naukovo-praktichnoï konferentsiï «Zabezpechennya stalogo rozvitku ekonomiki: problemi, mozhlivosti, perspektivi» (16-17 lyutogo 2018 roku, m. Uzhgorod), Ministerstvo osviti i nauki Ukraïni Uzhgorodsykiy natsionalyniy universitet, 2018, s. 127-131, ISBN 978-966-916-488-9 (Terziev, V., Banabakova, V., Georgiev, M. Assessment of the effectiveness of social programming. // Міжнародної науково-практичної конференції «Забезпечення сталого розвитку економіки: проблеми, можливості, перспективи» (16-17 лютого 2018 року, м. Ужгород), Міністерство освіти і науки України Ужгородський національний університет, 2018, с. 127-131, ISBN 978-966-916-4889).

Terziev, V., Banabakova, V., Georgiev, M. (2018r). The social program as a part of development strategies. // Mizhnarodnoï naukovo-praktichnoï konferentsiï «Zabezpechennya stalogo rozvitku ekonomiki: problemi, mozhlivosti, perspektivi» (16-17 lyutogo 2018 roku, m. Uzhgorod), Ministerstvo osviti i nauki Ukraïni Uzhgorodsykiy natsionalyniy universitet, 2018, s. 132-137, ISBN 978-966-916-488-9 (Terziev, V., Banabakova, V., Georgiev, M. The social program as a part of development strategies. // Міжнародної науково-практичної конференції «Забезпечення сталого розвитку економіки: 
IJASOS- International E-Journal of Advances in Social Sciences, Vol. IV, Issue 12, December 2018

проблеми, можливості, перспективи» (16-17 лютого 2018 року, м. Ужгород), Міністерство освіти і науки України Ужгородський національний університет, 2018, с. 132-137, ISBN 978-966-916-4889).

Terziev, V., Banabakova, V., Georgiev, M. (2018s). Social programming as a possibility to increase social efficiency. // Mizhnarodnoï naukovo-praktichnoï konferentsiï «Zabezpechennya stalogo rozvitku ekonomiki: problemi, mozhlivosti, perspektivi» (16-17 lyutogo 2018 roku, m. Uzhgorod), Ministerstvo osviti i nauki Ukraïni Uzhgorodsykiy natsionalyniy universitet, 2018, s. 137-142, ISBN 978-966-916488-9 (Terziev, V., Banabakova, V., Georgiev, M. Social programming as a possibility to increase social efficiency. // Міжнародної науково-практичної конференції «Забезпечення сталого розвитку економіки: проблеми, можливості, перспективи» (16-17 лютого 2018 року, м. Ужгород), Міністерство освіти і науки України Ужгородський національний університет, 2018, с. 137-142, ISBN 978-966-916-488-9).

Terziev, V., Georgiev, M. (2017a). Active social programs development in Bulgaria: Contemporary challenges and social management instruments. // International Journal of Humanities and Social Science Invention. www.ijhssi.org, 6, 2017, N 1, pp. 94-101, ISSN (Online): 2319 - 7722, ISSN (Print): 2319 - 7714.

Dimitrova, P., Georgiev, M. (2017b). Model of methodology for determining the needs of continuing vocationaltraining work specialists providing social services. // Innovatsii, tehnologii, nauka. Sbornik statey Mezhdunarodnoy nauchno - prakticheskoy konferentsii 25 yanvarya 2017 g., NITS Aeterna Permy, Chasty 4, 2017, s. 204-235, ISBN 978-5-906925-99-2, ISBN 978-5-00109-000-7 (Dimitrova, P., Georgiev M. Model of methodology for determining the needs of continuing vocationaltraining work specialists providing social services. // Инновации, технологии, наука. Сборник статей Международной научно - практической конференции 25 января 2017 г., НИЦ Аэтерна Пермь, Часть 4, 2017, с. 204-235, ISBN 978-5-906925-99-2, ISBN 978-5-00109-000-7).

Dimitrova, P., Georgiev, M. (2017c). Research, identification and monitoring of the needs of occupational training of social activities experts. // Innovatsii, tehnologii, nauka. Sbornik statey Mezhdunarodnoy nauchno - prakticheskoy konferentsii 25 yanvarya 2017 g., NITS Aeterna Permy, Chasty 4, 2017, s. 235-258, ISBN 978-5-906925-99-2, ISBN 978-5-00109-000-7 (Dimitrova, P., Georgiev M. Research, identification and monitoring of the needs of occupational training of social activities experts. // Инновации, технологии, наука. Сборник статей Международной научно - практической конференции 25 января 2017 г., НИЦ Аэтерна Пермь, Часть 4, 2017, с. 235-258, ISBN 978-5906925-99-2, ISBN 978-5-00109-000-7).

Terziev, V., Georgiev, M. (2017d). The active model of a social programme and ITS strategic advantage. // Medical Teacher. Taylor \& Francis, 39, 2017, N 12 (2), pp. 1418-1437, ISSN: 0142-159X (Print), ISSN: 1466-187X (Online).

Terziev, V., Georgiev, M. (2017e). Impact of the labor market policies for ensuring em-ployment. // Proceedings of Academics World 57th International Conference, Paris, France, 13th -14th February 2017, 2017, pp. 24-31, ISBN: 978-93-86083-34-0.

Terziev, V., Georgiev, M. (2017f). Importance of human resources to social development. // Proceedings of Academics World 57th International Conference, Paris, France, 13th -14th February 2017, 2017, pp. 32-34, ISBN: 978-93-86083-34-0.

Georgiev, Marin. (2017g). Impacts of active social programs on labor market. // Mezhdunarodnayy nauchnayy zhurnal «Innovatsionnaya nauka». NITS Aeterna, N 02-1, 2017, pp. 139-143 (Georgiev, Marin. Impacts of active social programs on labor market. // Международный научный журнал «Инновационная наука». НИЦ Аэтерна, N 02-1, 2017, pp. 139-143).

Terziev, V., Banabakova, V., Georgiev, M. (2017h). Razvitie i perestrukturirovanie zanyatosti v Bolgarii s nachala perehoda k raynochnoy ekonomike i v goday evropeyskoy integratsii. // Gromadsyka organizatsiya «Kiïvsykiy ekonomichniy naukoviy tsentr» Zbirnik materialiv vseukraïnsykoï naukovopraktichnoï konferentsiï «Pidpriemnitstvo, buhgaltersykiy oblik ta finansi: natsionalyni osoblivosti ta svitovi tendentsiï» 15-16 veresnya 2017 roku, Kiïv 2017, s.64-69 (Терзиев. В, Банабакова. В., Георгиев, М. Развитие и переструктурирование занятости в Болгарии с начала перехода к рыночной экономике и в годы европейской интеграции. // Громадська організація «Київський економічний науковий центр» Збірник матеріалів всеукраїнської науково-практичної конфреренції «Підприємництво, бухгалтерський облік та фінанси: національні особливості та світові тенденції» 15-16 вересня 2017 року, Київ 2017, с.64-69). 
IJASOS- International E-Journal of Advances in Social Sciences, Vol. IV, Issue 12, December 2018

Terziev, V., Banabakova, V., Georgiev, M. (2017i). Razvitie i perestrukturirovanie zanyatosti v Bolgarii. // Gromadsyka organizatsiya «Kiïvsykiy ekonomichniy naukoviy tsentr» Zbirnik materialiv vseukraïnsykoï naukovo-praktichnoï konferentsiï «Pidpriemnitstvo, buhgaltersykiy oblik ta finansi: natsionalyni osoblivosti ta svitovi tendentsiï» 15-16 veresnya 2017 roku, Kiïv 2017, s.70-75 (Терзиев. B, Банабакова. В., Георгиев, М. Развитие и переструктурирование занятости в Болгарии. // Громадська організація «Київський економічний науковий центр» Збірник матеріалів всеукраїнської науково-практичної конференції «Підприємництво, бухгалтерський облік та фінанси: національні особливості та світові тенденції» 15-16 вересня 2017 року, Київ 2017, с.7075).

Terziev, V., Banabakova, V., Georgiev, M. (2017j). Politiki dlya vozdeystviya i analiz sostoyaniya na raynok truda. // Gromadsyka organizatsiya «Kiïvsykiy ekonomichniy naukoviy tsentr» Zbirnik materialiv vseukraïnsykoï naukovo-praktichnoï konferentsiï «Pidpriemnitstvo, buhgaltersykiy oblik ta finansi: natsionalyni osoblivosti ta svitovi tendentsiï» 15-16 veresnya 2017 roku, Kiïv 2017, s.76-81 (Терзиев. В, Банабакова. В., Георгиев, М. Политики для воздействия и анализ состояния на рынок труда. // Громадська організація «Київський економічний науковий центр» Збірник матеріалів всеукраїнської науково-практичної конфреренції «Підприємництво, бухгалтерський облік та фінанси: національні особливості та світові тенденції» 15-16 вересня 2017 року, Київ 2017. с.7681).

Terziev, V., Banabakova, V., Georgiev, M. (2017k). Razvitie kontseptsii sotsialynoy ekonomiki. // Materiali dopovidey mizhnarodnoï naukovo - praktichnoï konferentsiï «Suchasni mozhlivosti zabezpechennya sotsialyno-ekonomichnogo rozvitku kraïn» 16 veresnya 2017 roku, Ministerstvo osviti i nauki Ukraïni, Uzhgorodsykiy natsionalyniy universitet, Fakulytet mizhnarodnih ekonomichnih vidnosin, Ekonomichniy fakulytet, Institut derzhavnogo upravlinnya ta regionalynogo rozvitku, Uzhgorod, 2017, s. 103-106, ISBN 978-966-916-348-6 (Терзиев. В, Банабакова. В., Георгиев, М. Развитие концепции социальной экономики. // Матеріали доповідей міжнародної науково - практичної конфреренції «Сучасні можливості забезпечення соціально-економічного розвитку країн» 16 вересня 2017 року, Міністерство освіти і науки України, Ужгородський національний університет, Факультет міжнародних економічних відносин, Економічний факультет, Інститут державного управління та регіонального розвитку, Ужгород, 2017, с. 103-106, ISBN 978-966-916-348-6).

Terziev, V., Banabakova, V., Georgiev, M. (2017I). Osobennosti, institutsii i znachenie razvitiya raynka truda. Materiali dopovidey mizhnarodnoï naukovo - praktichnoï konferentsiï «Suchasni mozhlivosti zabezpechennya sotsialyno-ekonomichnogo rozvitku kraïn» 16 veresnya 2017 roku, Ministerstvo osviti i nauki Ukraïni, Uzhgorodsykiy natsionalyniy universitet, Fakulytet mizhnarodnih ekonomichnih vidnosin, Ekonomichniy fakulytet, Institut derzhavnogo upravlinnya ta regionalynogo rozvitku, Uzhgorod, 2017, s. 100-103, ISBN 978-966-916-348-6 (Терзиев. В, Банабакова. В., Георгиев, М. Особенности, институции и значение развития рынка труда. Матеріали доповідей міжнародної науково - практичної конференції «Сучасні можливості забезпечення соціально-економічного розвитку країн» 16 вересня 2017 року, Міністерство освіти і науки України, Ужгородський національний університет, Факультет міжнародних економічних відносин, Економічний факультет, Інститут державного управління та регіонального розвитку, Ужгород, 2017, с. 100103, ISBN 978-966-916-348-6).

Terziev, V., Banabakova, V., Georgiev, M. (2017m). Osobennosti, institutsii i znachenie razvitiya raynka truda dlya dostizheniya ustoychivogo ekonomicheskogo i sotsialynogo razvitiya. // Materiali dopovidey mizhnarodnoï naukovo - praktichnoï konferentsiï «Suchasni mozhlivosti zabezpechennya sotsialynoekonomichnogo rozvitku kraïn» 16 veresnya 2017 roku, Ministerstvo osviti i nauki Ukraïni, Uzhgorodsykiy natsionalyniy universitet, Fakulytet mizhnarodnih ekonomichnih vidnosin, Ekonomichniy fakulytet, Institut derzhavnogo upravlinnya ta regionalynogo rozvitku, Uzhgorod, 2017, s. 97-100, ISBN 978-966-916-348-6 (Терзиев. В, Банабакова. В., Георгиев, М. Особенности, институции и значение развития рынка труда для достижения устойчивого экономического и социального развития. // Матеріали доповідей міжнародної науково - практичної конференції «Сучасні можливості забезпечення соціально-економічного розвитку країн» 16 вересня 2017 року, Міністерство освіти і науки України, Ужгородський національний університет, Факультет міжнародних економічних відносин, Економічний фракультет, Інститут державного управління та регіонального розвитку, Ужгород, 2017, с. 97-100, ISBN 978-966-916-348-6).

Terziev, V., Banabakova, V., Latyshev, O., Georgiev, M. (2017n). Opportunities of application of the balanced scorecard in management and control. // 3rd International Conference on Advances in Education and Social Sciences. International Organization Center of Academic Research, 
IJASOS- International E-Journal of Advances in Social Sciences, Vol. IV, Issue 12, December 2018

www.ocerint.org, 2017, pp. 773-791, ISBN: 978-605-82433-0-9.

Terziev, V., Nichev, N., Stoyanov, E., Georgiev, M. (20170). Key aspects of the problems of administrative control in Bulgaria. // Proceedings of ADVED 2017- 3rd International Conference on Advances in Education and Social Sciences 9-11 October 2017- Istanbul, Turkey. International Organization Center of Academic Research, www.ocerint.org, 2017, pp. 707-710, ISBN: 978-605-82433-0-9.

Terziev, V., Nichev, N., Stoyanov, E., Georgiev, M., Bogdanov, P. (2017p). Opportunities for strategic development of small business in Bulgaria. // Proceedings of ADVED 2017- 3rd International Conference on Advances in Education and Social Sciences 9-11 October 2017- Istanbul, Turkey. International Organization Center of Academic Research, www.ocerint.org, 2017, pp. 701-706, ISBN: 978-605-82433-0-9.

Terziev, V., Nichev, N., Stoyanov, E., Georgiev, M. (2017q). On some of the blank points in the application of administrative control in Bulgaria. // Proceedings of ADVED 2017- 3rd International Conference on Advances in Education and Social Sciences 9-11 October 2017- Istanbul, Turkey. International Organization Center of Academic Research, www.ocerint.org, 2017, pp. 695-700, ISBN: 978-60582433-0-9.

Terziev, V., Nichev, N., Stoyanov, E., Georgiev, M. (2017r). A general principle of the development process of Balanced scorecards as an instrument of control. // Proceedings of ADVED 2017-3rd International Conference on Advances in Education and Social Sciences 9-11 October 2017- Istanbul, Turkey. International Organization Center of Academic Research, www.ocerint.org, 2017, pp. 690-694, ISBN: 978-605-82433-0-9.

Terziev, V., Latyshev, O., Georgiev, M. (2017s). Building competencies for social work through continuing vocational training. // Proceedings of ADVED 2017- 3rd International Conference on Advances in Education and Social Sciences 9-11 October 2017- Istanbul, Turkey. International Organization Center of Academic Research, www.ocerint.org, 2017, pp.754-772, ISBN: 978-605-82433-0-9.

Terziev, V., Latyshev, O., Georgiev, M. (2017t). Building competencies for social work through continuing vocational training. // IJAEDU- International E-Journal of Advances in Education, International Organization Center of Academic Research, www.ocerint.org, 3, 2017, N 9, pp. 638-659, e-ISSN: 2411-18.

Terziev, V., Nichev, N., Stoyanov, E., Georgiev, M. (2017u). A general principle of the development process of Balanced scorecards as an instrument of control. // IJAEDU- International E-Journal of Advances in Education, International Organization Center of Academic Research, www.ocerint.org, 3, 2017, N 9 , pp. 888-892, e-ISSN: 2411-18.

Terziev, V., Nichev, N., Stoyanov, E., Georgiev, M. (2017v). On some of the blank points in the application of administrative control in Bulgaria. // IJAEDU- International E-Journal of Advances in Education, International Organization Center of Academic Research, www.ocerint.org, 3, 2017, N 9, pp. 893-898, e-ISSN: 2411-18

Terziev, V., Nichev, N., Stoyanov, E., Georgiev, M., Bogdanov, P. (2017w). Opportunities for strategic development of small business in Bulgaria. // IJAEDU- International E-Journal of Advances in Education, International Organization Center of Academic Research, www.ocerint.org, 3, 2017, N 9 , pp. 903-908, e-ISSN: 2411-18.

Terziev, V., Nichev, N., Stoyanov, E., Georgiev, M. (2017x). Key aspects of the problems of administrative control in Bulgaria. // IJAEDU- International E-Journal of Advances in Education, International Organization Center of Academic Research, www.ocerint.org, 3, 2017, N 9, pp. 909-912, e-ISSN: 2411-18.

Terziev, V., Banabakova, V., Latyshev, O., Georgiev, M. (2017y). Opportunities of application of the Balanced scorecard in management and control. // IJAEDU- International E-Journal of Advances in Education, International Organization Center of Academic Research, www.ocerint.org, 3, 2017, N 9 , pp. 1056-1074, e-ISSN: 2411-18. 